\title{
Besedotvorje in njegovi viri v slovanskih jezikih
}

\author{
Ines Voršič - Irena Stramljič Breznik
}

Cobiss: 1.19

Tvorba reči i njeni resursi u slovenskim jezicima: zbornik radova sa četrnaeste međunarodne naučne konferencije Komisije za tvorbu reči pri Međunarodnom komitetu slavista, ur. Rajna Dragićević, Beograd: Filološki fakultet, 2012, 771 str.

1 Od 28. do 30. maja 2012 je v Beogradu potekala že štirinajsta znanstvena konferenca Komisije za slovansko besedotvorje pri Mednarodnem slavističnem komiteju, in sicer na temo Besedotvorje in njegovi viri v slovanskih jezikih. Strokovno srečanje je potekalo v organizaciji Filološke fakultete v Beogradu in Biblioteke mesta Beograd ter pod odličnim vodstvom prof. dr. Boža Ćorića in prof. dr. Rajne Dragićević. Zbornik, ki je bil izdan ob tej priložnosti, je počastil tudi spomin na preminulo dolgoletno članico komisije dr. Jeleno A. Zemsko (5. 11. 1926 - 22. 3. 2012), katere besedotvorne raziskave so pomemben prispevek k slovanskemu besedotvorju in jezikoslovju sploh.

Na beograjski konferenci je sodelovalo skupno 63 referentov iz Avstrije, Belorusije, Bolgarije, Bosne in Hercegovine, Črne gore, Hrvaške, Makedonije, Nemčije, Poljske, Rusije, Slovaške, Slovenije, Srbije in Ukrajine. Referate so udeleženci predstavili ločeno v sekcijah A oz. B, skladno s tem pa so razvrščeni tudi v obsežnem zborniku, ki šteje kar 771 strani. Člani Komisije za slovansko besedotvorje so svoje delo predstavili v sklopu sekcije A.

Na zasedanju Komisije je bilo prisotnih 29 članov, ki pa so 29. maja 2012 odločili, da se vrsti strokovnjakov za besedotvorje pridružita dve novi članici, in sicer Larisa P. Kisljuk iz Ukrajine in Amela Šehović iz Bosne in Hercegovine. V zborniku sta njuna referata vključena med dela članov Komisije, prebrati pa je mogoče tudi prispevke članov, ki se konference niso mogli udeležiti, Igorja S. Uluhanova (Rusija), Valentine N. Vinogradove (Rusija) in Genadija A. Nikolajeva (Rusija). Zbornik v prvem delu (str. 21-433) tako zajema 34 prispevkov. Posebna pozornost je posvečena različnim tvorbenim postopkom - tako tradicionalnim, kot so izpeljava, zlaganje, sestavljanje, kot tudi manj tipičnim, kot so konverzija, univerbizacija in semantična tvorba, ki predstavljajo mejna področja besedotvorja.

2 Cvetanka D. Avramova (Sofija, Bolgarija) je na konferenci nastopila s prispevkom Nomina propria kot sredstvo tvorbe novih besed v sodobnem bolgarskem knjižnem jeziku (str. 21-31) in tako predstavila lastna imena, ki so zelo pogoste motivirajoče jezikovne enote za tvorbo novih besed. Lidija Arizankovska (Skopje, 
Makedonija) je predstavila makedonsko besedotvorje in tipična besedotvorna sredstva (str. 33-42), Julija M. Baltova (Sofija, Bolgarija) pa je razmišljala o t. i. »neoklasičnem « v sodobnem besedotvorju (str. 43-51). Razjasnila je pojma »neoklasicizem« in »neoklasično besedotvorje«, ki ju dobro pozna jezikoslovje germanskih jezikov, ter hkrati izpostavila potrebo po njuni ustalitvi v besedotvorni terminologiji slovanskih jezikov. Pri tem se je Baltova spraševala, ali obstaja razlika med zahodnoevropskim in slovanskim besedotvorjem, kadar le-to izhaja iz elementov, ki so izvorno iz grškega in latinskega jezika (npr. bio-, eko-, fono-, neo-, -teka ipd.), ob tovrstnih vprašanjih pa je opozorila tudi na nejasne ločnice med zlaganjem in prefiksacijo. Krystyna Waszakowa (Varšava, Poljska) je razpravljala o kognitivno-komunikacijski funkciji besedotvorne motivacije (str. 53-64). Valentina N. Vinogradova (Moskva, Rusija) se srečanja ni mogla udeležiti, v prispevku, objavljenem v zborniku (str. 65-72), pa je predstavila leksikalno-semantične in formalne lastnosti besedotvornih kategorij v poetičnih besedilih. Soorganizatorica beograjskega besedotvornega srečanja Rajna Dragićević (Beograd, Srbija) se je osredotočila na besedotvorno in semantično analizo izsamostalniških predlogov v sodobnem srbskem jeziku (str. 73-87), pri tem pa je izpostavila zlasti konverzijo - besedotvorni proces, ki privede do prehoda leksema iz ene besedne vrste $\mathrm{v}$ drugo. Raziskovanju konverzije kot tvorbenega postopka se je posvetila tudi Olga P. Jermakova (Kaluga, Rusija), ki je svoje ugotovitve predstavila v prispevku Konverzija in sinhronija (str. 89-96). Jevgenija A. Karpilovska (Kijev, Ukrajina) je opisala aktivne tvorbene vire sodobnega ukrajinskega jezika (str. 97-107), medtem ko je nova članica Komisije Larisa P. Kisljuk (Kijev, Ukrajina) razmišljala o diferenciaciji besedotvornih sredstev v sodobni ukrajinščini (str. 109-119). Krystyna Kleszczowa (Katovice, Poljska) je analizirala predloge v poljskem besedotvorju (str. 121-129), in sicer s ciljem, da potrdi tezo, da nestabilnost predlogov spodbuja spremembe $\mathrm{v}$ besedotvornem sistemu.

Nina F. Klimenko (Kijev, Ukrajina) se je posvetila raziskovanju regeneracije besedotvornih sredstev kot posledice semantične interference med jeziki (str. 131140). V sodobnem času zelo aktualno jeziko(slo)vno vprašanje pa je odprla Elena I. Koriakowcewa (Siedlce, Poljska), ki je v svojem referatu (str. 141-152) razglabljala o ekspresivni zmožnosti besedotvornih sredstev, pri čemer se je usmerila na strukturno in semantično analizo okazionalizmov, množično prisotnih v reklamnih besedilih, natančneje pa je preučila tvorjenke s t. i. polafiksi (angl. semi-affixes) tipa -holik, -oid, -fobia, -manija, -gate ipd. Predsednik Komisije za slovansko besedotvorje Aleksander Lukašanec (Minsk, Belorusija) je nastopil s prispevkom Nomina agentis v sodobnem beloruskem jeziku: besedotvorni potenciali in tendence (str. 153-165), v katerem je opozoril na težnje $\mathrm{k}$ internacionalizaciji, ki se aktivno kaže tudi v aktualni beloruščini, kar pomeni, da je (kot drugi slovanski jeziki) tudi beloruščina močno dovzetna za tujejezične elemente in jih je sposobna vključevati v lasten tvorbeni sistem. Jelena G. Lukašanec (Minsk, Belorusija) je predstavila prav tako izjemno aktualno raziskovalno temo, tj. besedotvorne pojave $\mathrm{v}$ internetni komunikaciji oz. tvorbene posebnosti, kot se odražajo v ruskem (spletnem) jeziku (str. 167-175), in sicer ne samo v spletnih klepetalnicah in na forumih, temveč tudi v spletnih slovarjih, ki jih oblikujejo internetni uporabniki in so tako leksikalni zaklad aktualnega pogovornega jezika, slenga in žargona zlasti mlajše populacije. Swetlana 
Mengel in Elena Plaksina (Berlin, Nemčija) sta razpravljali o interferenci besedotvornih mehanizmov v jezikovnem sistemu dvojezičnih govorcev (str. 177-192), kar sta storili ob naslonitvi na ruščino in njene »partnerske« jezike. Igor G. Miloslavski (Moskva, Rusija) je predstavil prispevek z naslovom Spremembe sintagmatskih in paradigmatskih značilnosti slovanskih glagolov kot rezultat semantične tvorbene modifikacije (str. 193-200).

Alicja Nagórko (Berlin, Nemčija) je raziskala besedotvorni potencial sakronimov v poljskem, slovaškem, češkem in nemškem jeziku (str. 201-214), pri tem pa se je naslonila na besednodružinsko analizo. Galina P. Neščimenko (Moskva, Rusija) je v daljšem prispevku (str. 215-233) razdelala pojav »preskoka« besedotvorne stopnje v tvorbenih procesih slovanskih jezikov. Aleksej V. Nikitevič (Grodno, Belorusija) je raziskal besedotvorne povezave narečnih podsistemov dveh sorodnih jezikov - beloruskega in ruskega (str. 235-243). Prispevek Genadija A. Nikolajeva (Kazan, Rusija), ki srečanju ni mogel prisostvovati, je osredinjen na univerbizacijo in substantivizacijo v zgodovini ruskega besedotvorja (str. 245-254). Slovaški jezikoslovec Martin Ološtiak (Prešov, Slovaška) je predstavil projekt, imenovan Kompleksna analiza besedotvorja sodobne slovaščine (str. 255-269), ki temelji na jezikovnem gradivu Slovarja korenskih morfemov slovaščine (2007). Cilj projekta sta celovit opis in razlaga funkcioniranja besedotvornega sistema slovaškega jezika tako s kvalitativnega kakor s kvantitativnega vidika. Jelena V. Petruhina (Moskva, Rusija) je proučila rabo besedotvornih sredstev cerkvenoslovanskega jezika v modernem ruskem jeziku in v primerjavi s srbskim jezikom (str. 271-287). Vasilka Radeva (Sofija, Bolgarija) je spregovorila o vlogi primerjave pri tvorbi besedotvornega pomena pridevnikov (str. 289-297), ki temelji na ideji izomorfizma med skladenjsko strukturo in besedotvornim pomenom tvorjenke, npr. sln. nebesnolep $<$ lep kot nebesa. Jochen Raecke (Tübingen, Nemčija) je v središče zanimanja postavil stanje slovanskega besedotvorja ter sredstva in predmet raziskovanja (str. 299-310), Zofia Rudnik-Karwatowa (Varšava, Poljska) pa je predstavila vlogo besedotvorja v slovanski jezikoslovni terminologiji (str. 311-318), pri čemer je izhajala iz gradiva poljskega, češkega in ruskega jezika. Ludwig Selimsky (Katovice, Poljska) je opisal elemente turškega jezika v bolgarskem besedotvornem sistemu (str. 319-329), pri tem pa se je v največji meri posvetil raziskavi turških obrazil, pripetih na avtohtone korene. Osrednja tema prispevka Jerzyja Sierociuka (Poznanj, Poljska) je specifika narečnega besedotvorja, kot jo izkazuje elektronski narečni korpus poljskega jezika (str. 331-340). Irena Stramljič Breznik (Maribor, Slovenija) je na konferenci predstavila medmete kot motivirajoče prvine za lastno in druge besedne vrste (str. 341-352). Branko Tošović (Gradec, Avstrija) je preučil teoretične vidike besedotvornega purizma ter podal njegovo pojmovanje in tipologijo, natančneje pa se je posvetil hrvaškemu, srbskemu, bosanskemu in črnogorskemu tvorbenemu purizmu (str. 353-365). Božo Ćorić (Beograd, Srbija), sogostitelj konference, je obširneje predstavil srbske tvorjenke s pomenom 'proizvod živalskega porekla' (str. 367-385) in jih analiziral s strukturnega in semantičnega vidika.

Igor S. Uluhanov (Moskva, Rusija) se je lotil obravnave besedotvornega postopka, imenovanega transafiksacija (angl. transaffixation) (str. 387-398). Zinaida A. Haritončik (Minsk, Belorusija) je razmišljala o konceptualni naravi leksikalnega 
- pomena (str. 399-406). Nova članica komisije Amela Šehović (Sarajevo, Bosna in [स Hercegovina) pa je v svojem prispevku (str. 407-417) pretresala vprašanje t. i. uniN verbizacije, katere pojmovna ustalitev v vseslovanskem jezikoslovju še ni povsem - utrjena, zaradi česar se dojema kot posebno zanimivo besedotvorno področje. \ Šehovićeva se je osredotočila na obravnavo »univerbov« v bosanskem jeziku, osnova za raziskavo pa ji je bilo poleg šrrokega jezikovnega korpusa pisnih besedil tudi besedje govorjenega jezika. Hrvaška jezikoslovka Barbara Štebih Golub (Zagreb, - Hrvaška) se je posvetila nadvse aktualni obravnavi priložnostnega besedja in raziskala okazionalizme v hrvaških publicističnih besedilih, izhajajoč iz korpusa hrvaških tiskanih in spletnih medijev. Obravnavane okazionalizme je v prispevku (str. 419-433) opredelila glede na stilno vrednost in besedotvorni status.

$3 \quad V$ drugem delu zbornika Besedotvorje in njegovi viri v slovanskih jezikih je mogoče prebrati še številne druge zanimive leksikološke prispevke jezikoslovcev iz Srbije in tudi iz Črne gore (napisali so jih M. S. Ajdžanović, M. B. Alanović, I. G. Bjelaković, V. Ž. Brborić, D. D. Veljković Stanković, D. M. Vitas in C. J. Krstev, D. S. Vujović, S. P. Vučković, C. Georgieva, D. S. Gortan-Premk, J. R. Jovanović Simić, D. B. Klikovac, V. D. Koprivica, I. V. Lazić-Konjik, B. Marić, त R. N. Marojević, J. I. Matijašević, A. M. Milanović, L. Nedeljkov, A. B. Pejanović, - P. T. Radić, S. Ristić, R. D. Simić, I. P. Ćelić, G. Štasni, G. Štrbac).

4 Po številu udeležencev oz. njihovih prispevkov je tako vnovič mogoče skleniti, da sta besedotvorje in leksikalni sistem izjemno aktualno raziskovalno področje s pestro raziskovalno dinamiko in pristopi. Zato je vzorno urejen, bogat in obsežen beograjski zbornik vreden pozornosti širše strokovne javnosti. 